ISSN 1392-3196 / e-ISSN 2335-8947

Zemdirbyste-Agriculture, vol. 101, No. 1 (2014), p. 51-56

DOI 10.13080/z-a.2014.101.007

\title{
Effect of UV-B radiation on growth and antioxidative enzymes activity in Lithuanian potato (Solanum tuberosum L.) cultivars
}

\author{
Regina VYŠNIAUSKIENĖ, Vida RANČELIENĖ \\ Nature Research Centre \\ Akademijos 2, Vilnius, Lithuania \\ E-mail: regina.vysniauskiene@botanika.lt
}

\begin{abstract}
The impact of ultraviolet-B (UV-B) radiation on most cultivated plants is negative. It reduces plant height and leaf area, increases leaf thickness and affects plant growth and development. The aim of this research was to compare the effects of UV-B on growth, photosynthetic pigments in potato cultivars and determine the activity of antioxidative enzymes in response mechanisms to the UV-B. Five Lithuania-bred potato (Solanum tuberosum L.) cultivars (three early, one medium and one late) were studied. The plants were treated with a UV-B radiation dose of $6 \mathrm{~kJ} \mathrm{~m}^{-2} \mathrm{~d}^{-1}$. The research demonstrated that after the UV-B exposure the plant height of early potato cultivars reduced. However, fresh and dry biomass of leaves, the concentrations of chlorophylls $a, b$ and carotenoids in potato cultivars remained unchanged after UV-B exposure compared to the control. Increased activity of antioxidative enzymes in potato cultivars after the UV-B radiation suggested an active plant response to UV-B-induced stress which depended on the plant genotype.
\end{abstract}

Key words: antioxidative enzymes, CAT, leaf pigments, SOD, Solanum tuberosum, UV-B.

\section{Introduction}

Climate changes have the most serious consequences on crop productivity. The levels of UV-B radiation in the biosphere vary depending on the constantly changing ozone layer, which affects our planet's life in all its forms, and particularly impacts plants. It has been estimated that the depletion of the ozone layer by $1 \%$ causes the increase of UV-B radiation by $2 \%$ (Scotto et al., 1988). UV-B radiation is harmful to most cultivated plants, depending on the plant species because it reduces plant height and leaf area and increases leaf thickness (Jansen, 2002). The impact of UV-B radiation on plants is commonly observed by decline in chlorophyll, flavonoids, proline content, which heavily effects plant productivity (Skórska, 2000; Zuk-Golaszewska et al., 2003; Santos et al., 2004). Higher doses of UV-B radiation in plant cells increase reactive oxygen species which cause ambivalent plant reactions: a part of reactive oxygen species causes oxidative stress and leads to irreversible oxidative damage of leaf tissues, another part activates the plant protection systems of different character (Mittler, 2002; Kakani et al., 2003). UV effect on plants occurs within the regulatory systems controlling plant response to stresscausing factor (Holley et al., 2003; Wu et al., 2011). Constantly exposed to changing climatic conditions and abiotic factors, plants have developed various protective systems, which directly stimulate the synthesis of protective materials: enzymatic antioxidants (Yannarelli et al., 2006; Baroniya et al., 2013) and non-enzymaticphenolic compounds, flavonoids (Xu, Sullivan, 2010), anthocyanins (Park et al., 2007). Ultraviolet radiation in tomatoes and tobacco activates pathogenesis-related (PR) protein synthesis, which directly may lead to increased resistance to pathogens (Barka et al., 2000; Fujibe et al., 2000; Charles et al., 2009), the increased hormone levels reduce fungal infection in dune grassland plants (Staaij et al., 2001).

Differences in UV-B sensitivity between cultivars of the same species have been investigated in rice (Oryza sativa L.) cultivars (Kumagai et al., 2001; Wu et al., 2011), wheat (Triticum aestivum L.) cultivars (Pinto et al., 2000) and cucumber (Cucumis sativus L.) cultivars (Tapia et al., 2010). Knowledge about potato cultivars' susceptibility to UV-B radiation is not yet available. Since potatoes are traditionally very important crop in Lithuania, we investigated the Lithuania-bred potato cultivars of different maturity, characterised by resistantce to late blight and other agents of diseases (Asakavičiūtè et al., 2007; Razukas et al., 2009). The aim of this research was to compare the effects of UV-B on different potato cultivars and determine the activity of antioxidative enzymes in response mechanisms to the $\mathrm{UV}-\mathrm{B}$ radiation. 


\section{Materials and methods}

Plant material and growth conditions. The Lithuania-bred potato (Solanum tuberosum L.) cultivars of different tuber maturity (very early 'Venta', early 'Goda' and 'Liepa', medium breeding line No. 2946-7 and very late 'Aista') were used for the research. The plants were cultivated in soil pots, in growth chambers at $25^{\circ} \mathrm{C}$ under a $16 / 8$-h light/dark cycle. Lamps OSRAM L 36/77 Fluora (Germany) (PAR $75 \mu \mathrm{m} \mathrm{m}^{-2} \mathrm{~s}^{-1}$ ) were used for illumination.

Ultraviolet-B (UV-B) irradiation conditions. After two weeks' growth, the plants were irradiated with UV-B lamps TL 20 W/12 RS ("Philips", Holland) at $6 \mathrm{~kJ} \mathrm{~m}^{-2} \mathrm{~d}^{-1}$ dose for 8 days. Plants not exposed to UV-B were used as a control. Plants were examined the next day after UV-B irradiation. The third and fourth leaves below apex were used for the analysis.

Plant growth measurements. The height of plants was measured. The third leaf below apex of each plant was used for the determination of fresh and dry leaf weight.

Extraction of soluble proteins. The fresh leaves (1 g) were homogenated in a $0.05 \mathrm{M} \mathrm{Na} / \mathrm{K}$ phosphate buffer (pH 7.8) and centrifuged at $12000 \mathrm{rpm}$ for 20 min. The supernatant was subjected to estimate the concentration of proteins with bovine serum albumin as the standard after Bradford (1976).

Superoxide dismutase (SOD), catalase (CAT) activity assay. The total SOD activity of leaf extracts was assayed by measuring its ability to inhibit the photochemical reduction of nitro-blue tetrazolium and measured using a spectrophotometer at $560 \mathrm{~nm}$ wavelengths after Beauchamp and Fridovich (1971). SOD isoforms in plant leaves were separated on native 9\% acrylamide gels after Laemmli (1970). The total CAT activity was measured spectrophotometrically at $25^{\circ} \mathrm{C}$ by following the decline in $240 \mathrm{~nm}$ as $\mathrm{H}_{2} \mathrm{O}_{2}$ was catabolised, as described by Aebi (1984).

The concentration of chlorophylls $a, b$ and carotenoids. The pigments were extracted with DMF ( $N, N$-dimethylformamide). The concentrations of chlorophylls $a$ (Chl-a), $b$ (Chl-b) and carotenoids were determined spectrophotometrically (Wellburn, 1994).

Statistical analysis. The experiments were replicated three times. The results were expressed as mean values and their confidence intervals. The significance of differences between the control and UV-B exposed plants was analysed using the Student's $t$-test for comparison of means at the level of significance of $p<0.05$.

\section{Results and discussion}

Damaging UV-B radiation dose induces mostly morphological and metabolic changes in plants. The data of our previous research suggested that under the impact of UV-B $8 \mathrm{~kJ} \mathrm{~m}^{-2} \mathrm{~d}^{-1}$ dose morphological characteristics of somatic interspecific potatoes Solanum comersonii and S. tuberosum was affected negatively (Vyšniauskienè et al., 2007). In the present study, we applied a smaller, $6 \mathrm{~kJ} \mathrm{~m}^{-2} \mathrm{~d}^{-1}$ dose. The object of investigation was the potato cultivars of different tuber maturity: from very early to very late. Our results showed a decrease in the height of early potato cultivars under UV-B radiation (Fig. 1).

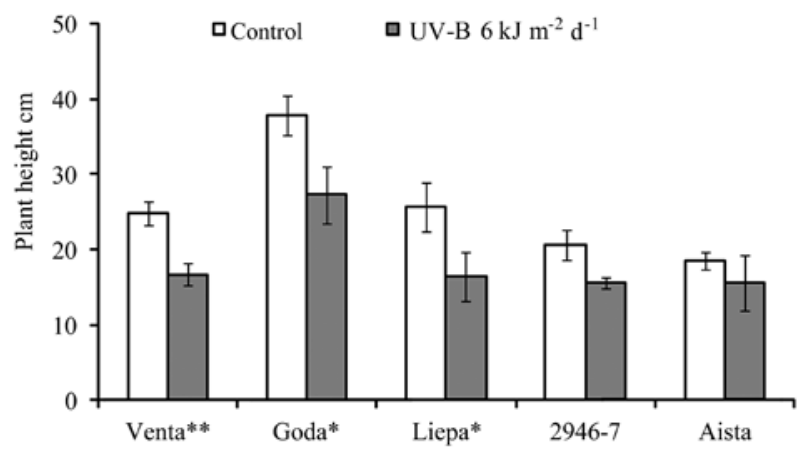

Notes. Asterisks designate statistically significant difference between the control and the UV-B exposed plants $(*-p<0.05$, $* *-p<0.01)$.

Figure 1. The effect of ultraviolet-B (UV-B) $6 \mathrm{~kJ} \mathrm{~m}^{-2} \mathrm{~d}^{-1}$ dose radiation on potato height

After UV-B exposure, a reduction in fresh and dry weight of leaves was observed only in very late cultivar 'Aista'. Fresh and dry leaf weight in early 'Liepa' and medium 2946-7 remained unchanged after UV-B exposure (Fig. 2). Compared with the control, the slight changes in dry leaf weight after $6 \mathrm{~kJ} \mathrm{~m}^{-2} \mathrm{~d}^{-1} \mathrm{UV}$-B dose exposure were within the error range and insignificant.

One of the causes of plant growth reduction is directly related to the system of plant photosynthesis, which leads to diminishing plant productivity and yield. The suppressed plant growth and reduced biomass production caused by oxidative stress are attributed to the decrease of the photosynthetic activity in plants typical of most cultivated plants; however, Hao et al. (2000) have observed that in tomatoes, UV-B radiation decreased the heights of plants, but increased chlorophyll concentration in leaves. Our tests demonstrated that the concentrations of chlorophylls $a, b$ and carotenoids increased in very early 'Venta', early 'Goda'; however, these data are not significant. In other cultivars the impact of UV-B on photosyntetic pigments was not recorded (Fig. 3). Therefore, compared with the control, the $6 \mathrm{~kJ} \mathrm{~m}^{-2} \mathrm{~d}^{-1}$ UV-B dose had no effect on either fresh or dry weight of leaves as well as on the concentration of photosyntetic pigments.

After the UV-B exposure protein concentration levels increased in the leaves of early cultivars 'Liepa', medium No. 2946-7 and late 'Aista', whereas they significantly decreased in the leaves of cultivars 'Venta' and slightly in 'Goda' (Fig. 4). During recent proteomic studies on Oryza sativa (Wu et al., 2011), 39 proteins upor downregulated, following the UV-B radiation, have been identified. These identified proteins were mostly upregulated in UV-B-tolerant cultivars of rice, while less than half of them were downregulated in UV-B-sensitive cultivars of rice. Therefore, following UV-B radiation, different protein groups involved in plant response can be upregulated or downregulated, which depends on the plant genotype. SOD activity after UV-B exposure 

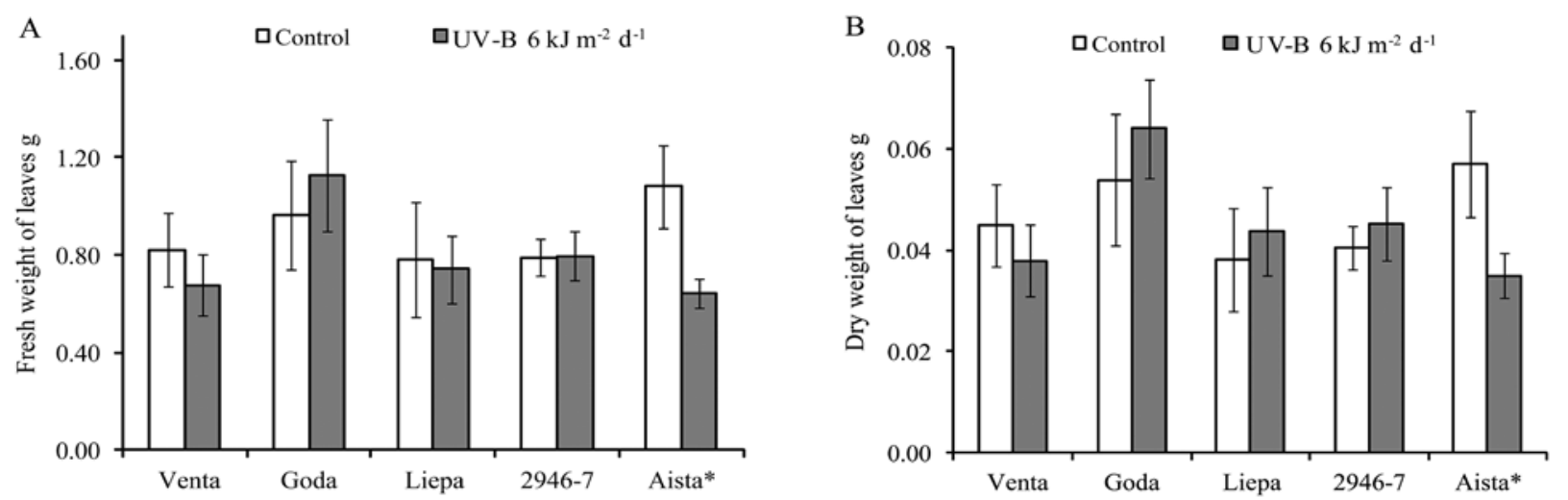

Note.Asterisk designates statistically significant difference between the control and the UV-B exposed plants $(*-p<0.05)$.

Figure 2. The fresh (A) and dry (B) weight of leaves of potato cultivars after an 8-day ultraviolet-B (UV-B) $6 \mathrm{~kJ} \mathrm{~m}^{-2}$ $\mathrm{d}^{-1}$ dose radiation
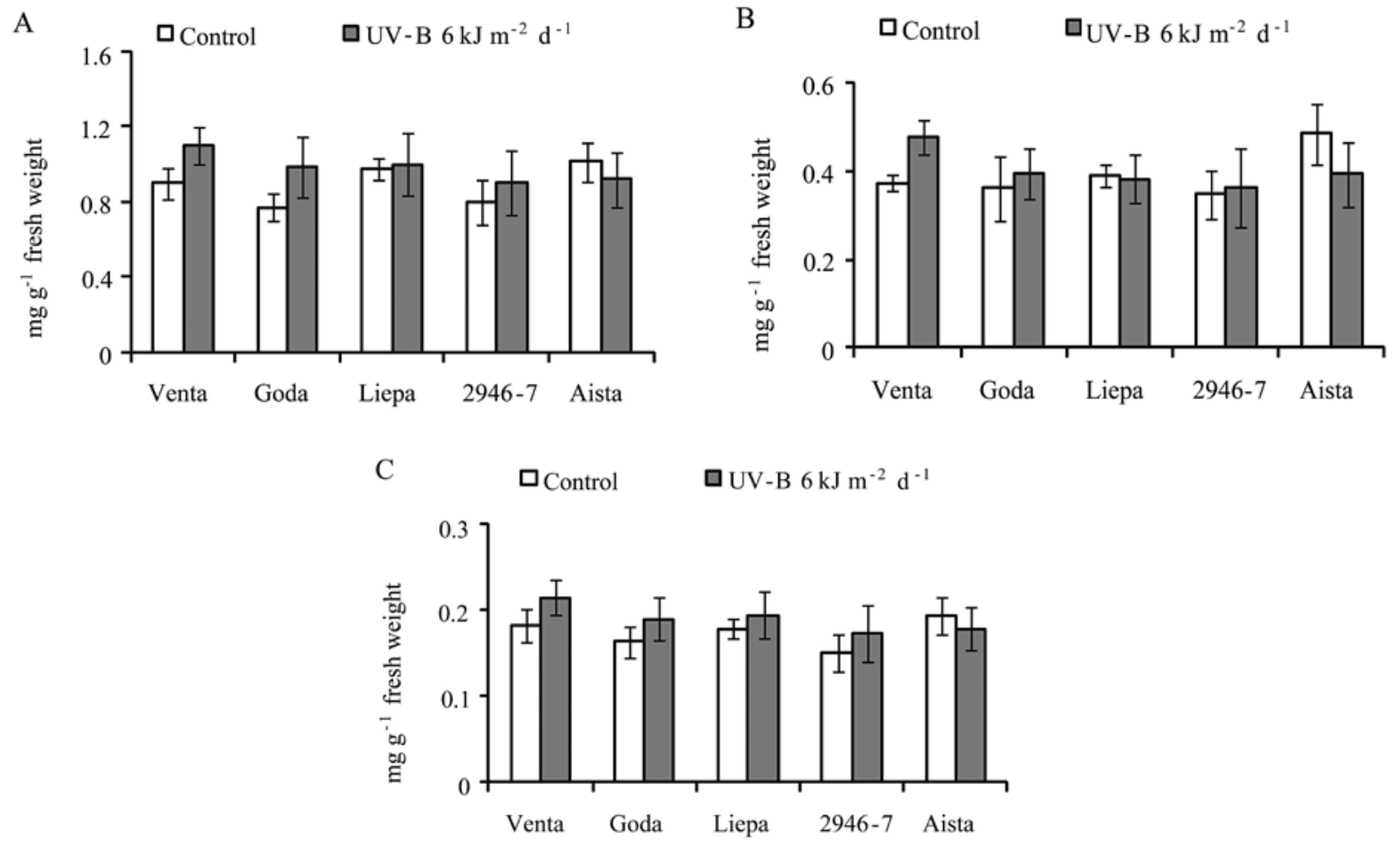

Figure 3. The effect of ultraviolet-B (UV-B) $6 \mathrm{~kJ} \mathrm{~m}^{-2} \mathrm{~d}^{-1}$ dose radiation on photosynthetic pigments (A - chlorophyll $a, \mathrm{~B}$ - chlorophyll $b, \mathrm{C}$ - carotenoids) in potato leaves

in very early 'Venta' and very late 'Aista' remained the same as in the control, whereas in the early 'Goda' and medium No. 2946-7 cultivars SOD increased about 1.5fold compared to the control. The studies on CAT activity after UV-B radiation demonstrated that in very early 'Venta' and early 'Liepa', CAT enzyme activity in plant leaves increased 1.9-fold and 1.6-fold, but in very late cultivar 'Aista', CAT activity increased significantly less, whereas in early 'Goda', medium No. 2946-7 remained close to the control level (Fig. 4).

Such a difference in the response of antioxidative enzymes to UV-B effects is potentially associated with different genetic nature of potato cultivars, because these potato cultivars have different genotype (Asakavičiūte et al., 2007). The effect of UV-B radiation on SOD pattern by electrophoresis showed that UV-B does not induce the appearance of new SOD isoforms in UV-B treated plants, but increases the activity of some isoforms, which advances the general SOD activity compared with the control (Fig. 5).

It should be mentioned that the tested cultivars are characterized by different spectra of SOD isoforms - from 7 to 8 bands. The antioxidative enzyme systems may be participating in the plant defence mechanisms against oxidative damage. SOD and CAT enzymes protect the plant, therefore, activation of their synthesis can be explained by stimulatory UV-B effect of $6 \mathrm{~kJ} \mathrm{~m}^{-2} \mathrm{~d}^{-1}$ dose in potatoes, which was demonstrated in our tests. The $6 \mathrm{~kJ} \mathrm{~m}^{-2} \mathrm{~d}^{-1}$ UV-B dose did not influence the synthesis of chlorophyll, fresh and dry leaf weight but reduced plant height. 

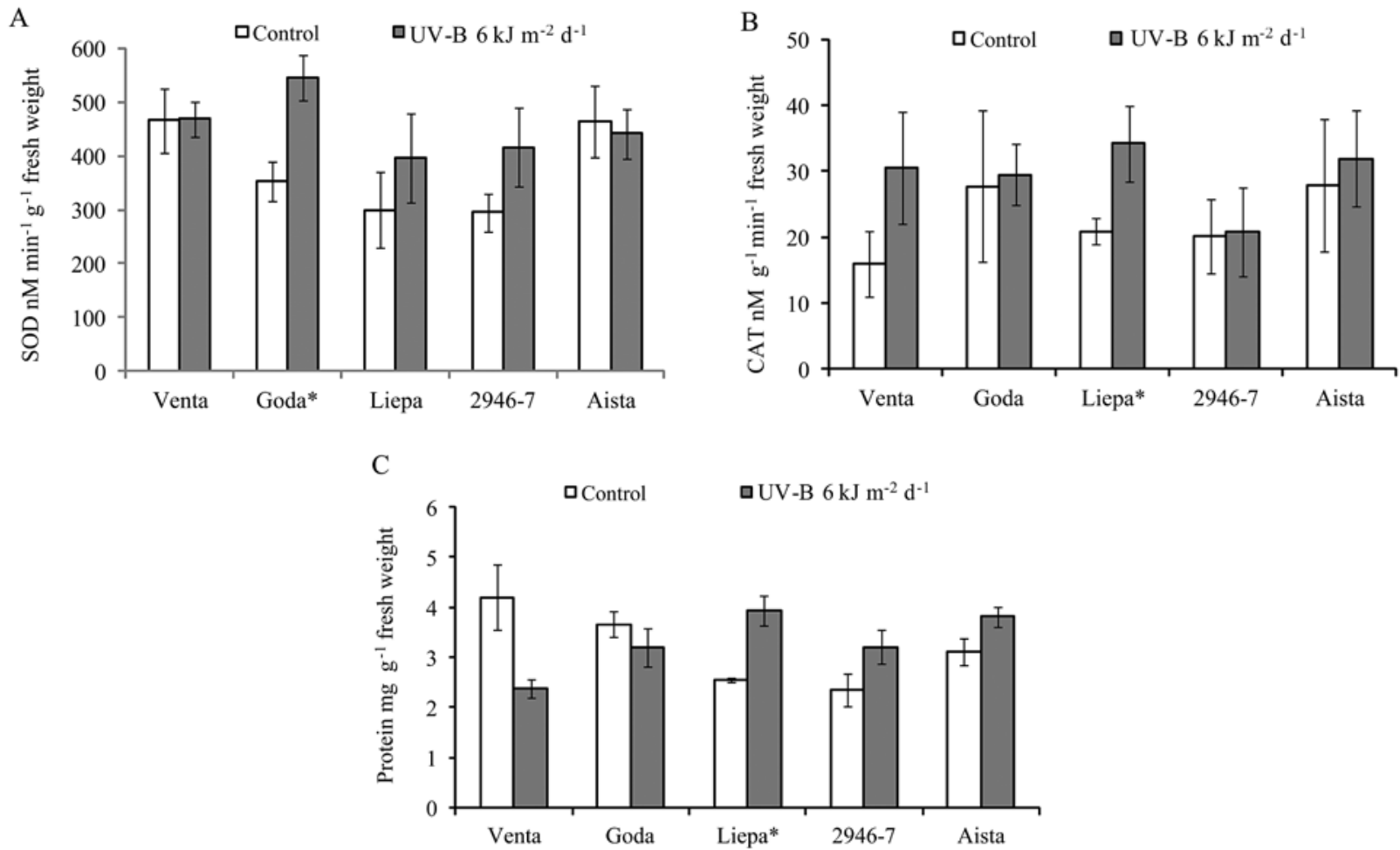

Note. Asterisk designates statistically significant difference between the control and the UV-B exposed plants $(*-p<0.05)$.

Figure 4. The effect of ultraviolet-B (UV-B) $6 \mathrm{~kJ} \mathrm{~m}^{-2} \mathrm{~d}^{-1}$ dose radiation on the activity of antioxidative enzymes superoxide dismutase (SOD) (A), calatase (CAT) (B) and total proteins (C) in potato leaves

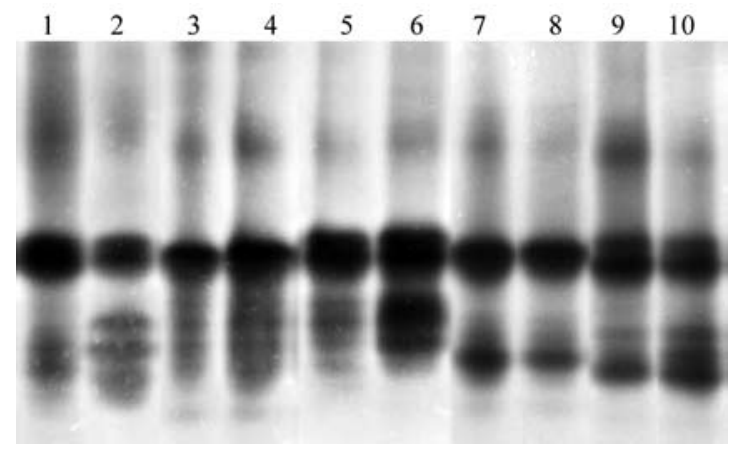

Cultivars: 1, 2 - very early 'Venta', 3, 4- early 'Goda', 5, 6 - early 'Liepa', 7, 8 - medium No. 2946-7, 9, 10 - very late 'Aista'; 1, 3, 5, 7, 9 - control, 2, 4, 6, 8, 10 - UV-B irradiated

Figure 5. Superoxide dismutase (SOD) isoform pattern of leaf proteins extracts from potato exposed to ultraviolet-B (UV-B) radiation

In response to stressors, plant mobilizes various protective materials: antioxidant enzymes, signal and PRproteins, flavonoids and phenylpropanoids, hormones, and this feature can be applied to increase the synthesis of plant-produced biologically valuable materials; however, the response and stress-induced effects depend on the plant species, intraspecific diversity, and genotype characteristics (Kalbina, Strid, 2006; Wu et al., 2011; Baroniya et al., 2013). In our previous studies we demonstrated that interspecific somatic potato hybrids resistant to cold after UV-B $8 \mathrm{~kJ} \mathrm{~m}^{-2} \mathrm{~d}^{-1}$ dose exposure, induced two new SOD isoforms, indicating that hybrids are also more tolerant to another environmental factor - UV-B radiation (Vyšniauskienè et al., 2007). The increased antioxidative activity of SOD and CAT enzymes in potato cultivars shows an active response of early potato cultivars to UV-B-induced stress. While studying the responses of potato cultivars to UV-B 6 $\mathrm{kJ} \mathrm{m}^{-2} \mathrm{~d}^{-1}$ dose radiation, we found that SOD and CAT enzyme activity and protein content alterations after UV-B exposure depended on the plant genotype.

\section{Conclusions}

1. The $6 \mathrm{~kJ} \mathrm{~m}^{-2} \mathrm{~d}^{-1}$ ultraviolet-B (UV-B) dose reduced the height of early potato cultivars.

2. The fresh and dry biomass of leaves, the concentrations of chlorophylls $a, b$ and carotenoids in all potato cultivars remained unchanged after UV-B exposure compared to the control.

3. Increased activity of antioxidative enzymes in potato cultivars after the UV-B radiation suggested an active plant response to UV-B-induced stress which depended on the plant genotype.

\section{Acknowledgements}

The authors thank Dr. J. Jundulas for the provision of potato cultivars for the research. The study was supported partly by COST Action FA 0906 . We thank V. Ptašekienė for linguistic assistance.

Received 07032013 Accepted 28072013 


\section{References}

Aebi H. 1984. Catalase in vitro. Packer L. (ed.). Methods in enzymology, 105: 121-126

Asakavičiūtè R., Jundulas J., Ražukas A. 2007. Research on potato (Solanum tuberosum L.) genetic resourses in Lithuania. Zemdirbystè-Agriculture, 94 (4): 48-55

Barka E. A., Kalantari S., Makhlouf J., Arul J. 2000. Impact of UV-C irradiation on the cell wall-degrading enzymes during ripening of tomato (Lycopersicon esculentum L.) fruit. Journal of Agricultural and Food Chemistry, 48 (3): 667-671 http://dx.doi.org/10.1021/jf9906174

Baroniya S. S., Kataria S., Pandey G. P. Guruprasad K. N. 2013. Intraspecific variations in antioxidant defense responses and sensitivity of soybean varieties to ambient UV radiation. Acta Physiologiae Plantarum, 35 (5): 1521 $1530 \mathrm{http}: / /$ dx.doi.org/10.1007/s11738-012-1193-6

Beauchamp C. O., Fridovich I. 1971. Superoxide dismutase: improved assays and an assay applicable to acrylamide gels. Analytical Biochemistry, 44 (1): 276-287 http://dx.doi.org/10.1016/0003-2697(71)90370-8

Bradford M. N. 1976. A rapid and sensitive method for the quantification of microgram quantities of protein utilizing the principle of protein-dye binding. Analytical Biochemistry, 72 (1-2): 248-257 http://dx.doi.org/10.1016/0003-2697(76)90527-3

Charles M. T., Tano K., Asselin A., Arul J. 2009. Physiological basis of UV-C induced resistance to Botrytis cinerea in tomato fruit. V. Constitutive defence enzymes and inducible pathogenesis-related proteins. Postharvest Biology and Technology, 51 (3): 414-424 http://dx.doi.org/10.1016/j.postharvbio.2008.08.016

Fujibe T., Watanabe K., Nakajima N. Ohashi Y., Mitsuhara I., Yamamoto K. T., Takeuchi Y. 2000. Accumulation of pathogenesis-related proteins in tobacco leaves irradiated with UV-B. Journal of Plant Research, 113 (4): 387-394 http://dx.doi.org/10.1007/PL00013946

Hao X., Hale B. A., Ormrod D. P., Papadopoulos A. P. 2000. Effects of pre-exposure to ultraviolet-B radiation on responses of tomato (Lycopersicon esculentum cv. New Yorker) to ozone in ambient and elevated carbondioxide. Environmental Pollution, 110 (2): 217-224 http://dx.doi.org/10.1016/S0269-7491(99)00305-X

Holley S. R., Yalamanchili R. D., Moura D. S, Ryan C. A., Stratmann J. W. 2003. Convergence of signaling pathways induced by systemin oligosaccharide elicitors, and ultraviolet-B radiation at the level of mitogen-activated protein kinases in wild tomato suspension-cultured cells. Plant Physiology, 132 (4): 1728-1738 http://dx.doi.org/10.1104/pp.103.024414

Jansen M. A. K. 2002. Ultraviolet-B radiation effects on plants: induction of morphogenetic responses. Physiologia Plantarum, 116 (3): 423-429 Kalbina I., Strid A. 2006. Supplementary ultraviolet-B irradiation reveals differences in stress responses between Arabidopsis thaliana ecotypes. Plant, Cell and Environment, 29 (5): 754-763

Kakani V. G., Reddy K. R., Zhao D., Sailaja K. 2003. Field crop response to ultraviolet-B radiation: a review. Agricultural and Forest Meteorology, 120 (1-4): 191-218 http://dx.doi.org/10.1016/j.agrformet.2003.08.015

Kalbina I., Strid A. 2006. Supplementary ultraviolet-B irradiation reveals differences in stress responses between Arabidopsis thaliana ecotypes. Plant, Cell and Environment, 29 (5): 754-763 http://dx.doi.org/10.1111/j.1365-3040.2005.01436.x
Kumagai T., Ilidema J., Kang I., Sato T. 2001. Effects of supplemental UV-B radiation on the growth and yield of two cultivars of Japanese lowland rice (Oryza sativa L.) under the field in a cool rice-growing region of Japan. Agriculture, Ecosystems and Environment, 83 (1-2): $201-$ $208 \mathrm{http}: / /$ dx.doi.org/10.1016/S0167-8809(00)00180-8

Laemmli V. K. 1970. Cleavage of structural proteins during the assembly of the head of bacteriophage T4. Nature, 227 (5259): 680-685 http://dx.doi.org/10.1038/227680a0

Mittler R. 2002. Oxidative stress, antioxidants and stress tolerance. Trends in Plant Science, 7 (9): 405-410 http://dx.doi.org/10.1016/S1360-1385(02)02312-9

Park J. S., Choung M. G., Kim J. B., Hahn B. S, Kim J. B., Bae S. C., Roh K. H., Kim Y. H., Cheon C. I., Sung M. K., Cho K. J. 2007. Genes up-regulated during red coloration in UV-B irradiated lettuce leaves. Plant Cell Reports, 26 (4): 507-516 http://dx.doi.org/10.1007/s00299-006-0255-x

Pinto M., Lizana C., Pastenes C., Riquelme A., Berti M. 2000. Effect of the ultraviolet-B radiation on growth and photosynthesis of seven varieties of wheat (Triticum aestivum L.). Revista Chilena Historia Natural, 73 (1): $55-66$

Razukas A., Jankauskiene Z., Jundulas J., Asakaviciute R. 2009. Research of technical crops (potato and flax) genetic resources in Lithuania. Agronomy Research, 7 (1): 59-72

Santos I., Fidalgo F., Almeidaand J. M., Salema R. 2004. Biochemical and ultrastructural changes in leaves of potato plants grown under supplementary UV-B radiation. Plant Science, 167 (4): 925-935 http://dx.doi.org/10.1016/j.plantsci.2004.05.035

Scotto J., Cotton G., Urbach F., Berger D., Fears T. 1988. Biological effective ultraviolet radiation: surface measurements in the United States, 1974 to 1985 . Science, 239 (4841): 762-764 http://dx.doi.org/10.1126/science.3340857

Skórska E. 2000. Responses of pea and triticale photosynthesis and growth to long-wave UV-B radiation. Biologia Plantarum, 43 (1): 129-131 http://dx.doi.org/10.1023/A:1026523617988

Staaij J., Rozema J., Beem A., Aerts R. 2001. Increased solar UV-B radiation may reduce infection by arbuscular mycorrhizal fungi (AMF) in dune grassland plants: evidence from five years of field exposure. Plant Ecology, 154 (1-2): 169-177 http://dx.doi.org/10.1023/A:1012975605995

Tapia M. L. F., Toro G. A., Parra B. R., Riquelme A. E. 2010. Photosensitivity of cucumber (Cucumis sativus L.) seedlings exposed to ultraviolet-B radiation. Chilean Journal of Agricultural Research, 70 (1): 16-25 http://dx.doi.org/10.4067/S0718-58392010000100002

Vyšniauskienė R., Rančelienė V., Radžiūnaitė-Paukštienė A., Spalinskas R. 2007. The UV-B impact upon the enzyme of antioxidant system superoxide dismutase (SOD) of potato somatic hybrids. Biologija, 53 (2):67-70

Wellburn A. R. 1994. The spectral determination of chlorophylls $a$ and $b$, as well as total carotenoids, using various solvents with spectrophotometers of different resolution. Journal of Plant Physiology, 144 (3): 307-313 http://dx.doi.org/10.1016/S0176-1617(11)81192-2

Wu X. C., Fang C. X., Chen J. Y., Wang Q. S., Chen T., Lin W. X. 2011. A proteomic analysis of leaf responses to enhanced ultraviolet-B radiation in two rice (Oryza sativa L.) cultivars differing in UV sensitivity. Journal of Plant Biology, 54 (4): 251-261 http://dx.doi.org/10.1007/s12374-011-9162-y 
Xu C., Sullivan J. H. 2010. Reviewing the technical designs for experiments with ultraviolet-B radiation and impact on photosynthesis, DNA and secondary metabolism. Journal of Integrative Plant Biology, 52 (4): 377-387 http://dx.doi.org/10.1111/j.1744-7909.2010.00939.x

Yannarelli G. G., Noriega G. O., Batlle A. Tomaro M. L. 2006. Heme oxygenase up-regulation in ultraviolet-B irradiated soybean plants involves reactive oxygen species. Planta, 224 (5): 1154-1162

http://dx.doi.org/10.1007/s00425-006-0297-x

Zuk-Golaszewska K., Upadhyaya M. K., Golaszewski J. 2003. The effect of UV-B radiation on plant growth and development. Plant, Soil and Environment, 49 (3): 135-140

ISSN 1392-3196 / e-ISSN 2335-8947

Zemdirbyste-Agriculture, vol. 101, No. 1 (2014), p. 51-56

DOI 10.13080/z-a.2014.101.007

\section{Augimo ir antioksidacinių fermentų aktyvumo pokyčiai po UV-B poveikio lietuviškos kilmès veislių valgomosiose bulvèse (Solanum tuberosum L.)}

R. Vyšniauskienè, V. Rančelienė

Gamtos tyrimų centras

\section{Santrauka}

Daugumą kultūrinių augalų ultravioletinè-B (UV-B) spinduliuotė veikia neigiamai: mažina jų aukštị ir lapų plotą, didina lapų storį. Šie pakitimai veikia augalų augimą ir vystymąsi. Tyrimų tikslas - palyginti UV-B poveikị skirtingų veislių bulvių augalų augimui, fotosintetiniams pigmentams ir nustatyti antioksidacinių fermentų ịtaką atsakui ị UV-B poveikị. Tirtos valgomosios bulvès (Solanum tuberosum L.) penkios lietuviškos veislès: trys ankstyvosios, viena vidutinio ankstyvumo ir viena vèlyva. Bulvès paveiktos $6 \mathrm{~kJ} \mathrm{~m}^{-2} \mathrm{~d}^{-1} \mathrm{UV}$-B spinduliuotès doze. Tyrimų duomenys parodè, kad po UV-B poveikio sumažèjo ankstyvujų bulvių augalų aukštis. Po UV-B poveikio visų veislių bulvių žalia ir sausa biomasès, chlorofilų $a, b$ ir karotenoidų koncentracija liko nepakitusi, lyginant su kontroliniu variantu. Po UV-B spinduliuotès poveikio padidėjęs bulvių antioksidacinių fermentų aktyvumas rodè aktyvų augalų atsaką i UV-B sukeltą stresą, kuris priklauso nuo augalo genotipo.

Reikšminiai žodžiai: antioksidaciniai fermentai, CAT, lapų pigmentai, SOD, Solanum tuberosum, UV-B. 